\title{
Changes in the water surface area of Lakes Udzierz and Mątasek in the light of cartographic materials
}

\author{
Andrzej Fabich, Monika Kwidzińska \\ Department of Limnology, Institute of Geography, University of Gdańsk, Bażyńskiego 4, 80-952 Gdańsk, Poland, e-mail; \\ andrzejfabich@op.pl,monika.kwidzinska@onet.eu
}

\begin{abstract}
The paper presents the changes in the water surface area of Lakes Udzierz and Matasek located in the headwaters of the catchment of the River Mątawa (tributary of the River Vistula). The assessment of the rate of changes was based on Polish and German topographic maps as well as orthophotomaps. The analysed lakes turned out to be two of the fastest disappearing Polish lakes. In the last century (1910-2010) the water surface area of Lake Udzierz decreased from 148.87 to 69.60 ha and that of Lake Mątasek from 29.5 to 0.64 ha. The average rate of loss of the lake surface area during this period was from 0.53 to $0.98 \%$ per annum. Such drastic morphometric changes in the studied lakes are, on the one hand, mainly due to poorly conducted drainage and, on the other hand, the eutrophication of the lake waters intensified by the anthropogenic impact.
\end{abstract}

Keywords: Lake Udzierz, Lake Mątasek, Kociewie Region, Tuchola Forest, disappearance of lakes

\section{Introduction}

Lakes are a characteristic component of the natural environment of young post-glacial areas. In the geological time scale, they are the least permanent landscape element (Starkel 1977; Lange 1986). A specific feature of lakes is, in fact, a positive balance of energy and matter, which means that lakes are accumulating systems (Rossolimo 1964). In the ever changing geographical environment lakes undergo natural transformation processes, which in the evolutionary development of lakes lead to their eventual disappearance. The visible signs of lakes' ecological succession are changes in their morphometry (Stangenberg 1936; Choiński et al. 2011) and water quality characteristics (Stangenberg 1936; Churski 1983; Choiński et al. 2011).

The contemporary evolution of lakes and the observed accelerated pace of their disappearance, however, are strongly associated with human economic activity that often disrupts the natural transformation processes. In natural conditions, the evolution of lakes is usually very slow. Anthropogenic changes, however, often occur quickly and rapidly, leading to the disappearance of lakes in just a few or several years (Marszelewski 2005). The most important forms of human impact on lake ecosystems appear to include drainage procedures (Babiński 1988; Du et al. 2011), anthropogenic eutrophication (Vollenveider 1970; Churski 1983), lowering the groundwater level (Kunz et al. 2010; Kawanabe et al. 2012), land use changes (Kopytowski 1931; Sidle et al. 2007), water intake for irrigation (Belyaev 1995; Gao et al. 2011) and global warming (Bai et al. 2011; Huang et al. 2011).

For years, changes in lake surface area have been an important research problem undertaken by limnologists. This issue is considered both for large geographical regions (Marszelewski 2005; Bai et al. 2011; Choiński et al. 2011; Huang et al. 2011) as well as on a local scale (Jureko 1969; Babiński 1988; Kunz et al. 2010). The importance of these studies is mainly due to the role lakes play in the natural environment and economy. Lakes are important regulators of the water and energy exchange with the surroundings (Lange 1983) and of circulation of chemical elements (Tranvik et al. 2009). Due to their high productivity, lakes are also important habitats for biodiversity conservation (Hillbricht-Ilkowska 2005; Dudgeoni et al. 
2006), and they play a key role in the economic development of many regions (fishing, tourism, drinking water supplies) (Sarch 2001).

Studies on the disappearance of lakes in Poland were initiated by Galon (1954) and Kalinowska (1961). Their studies show that the vast majority of lakes in Poland are currently in the advanced stage of disappearance, and the percentage of the surviving original water surface area of the early Holocene lakes is only $30 \%$. In the last century, as a result of anthropogenic impact, the process of lake disappearance intensified. At that time, the water surface area of the lakes in the Greater Poland-Kuyavian Lakeland decreased by 19.2\% (Nowacka and Ptak 2007), in the Chełmno Lakeland by 16.7\% (Marszelewski and Podgórski 2004), in the Kashubian Lakeland by $4.3 \%$ (Czaja and Jańczak (2010), and in the Great Masurian Lakes by 3.7\% (Marszelewski and Adamczyk 2004). Any lake with its alimentation area (catchment) is a separate geoecosystem (Kostrzewski 1993), hence the need for an individualised research approach. The most dramatic morphometric changes are observed in relation to individual objects, rather than their larger groupings. The diagnosis of the causes of changes in individual lakes may help in the assessment of the most significant threats to the further existence of these hydrographic objects in the environment and, consequently, affect the undertaking of effective protective measures.

The primary documentary materials for the assessment of the recent changes in the lake surface area are cartographic and photogrammetric materials, both archival and contemporary.

The purpose of this study was to determine the tendency and rate of changes to the water surface area of Lakes Udzierz and Mątasek observed in the last century.

\section{Methods}

The analysis of the long-term changes in the water surface area of Lakes Udzierz and Mątasek was based on the cartographic and photogrammetric materials meeting the principles of geomatics and produced between the early $20^{\text {th }}$ and the early $21^{\text {st }} \mathrm{c}$.

The oldest maps used in the study were the German topographic maps Topografische Karten (Meßtischblätter) from 1910 and 1938, published in the scale of 1:25 000 by Königliche Preussische Landesaufnahme - Reichsamt für Landesaufnahme. The other materi- als, the topographic maps and orthophotos, were produced by the Polish Geodetic and Cartographic Service. The oldest among them included the topographic map dated 1969 drawn in the scale of 1:50 000, and the topographic maps from 1973 made in the scale of 1:25 000. The topographic maps of 1991 made in the scale of 1:10 000 had the more current cartographic contents. In addition, the hydrographic maps published in the years 2006-2008, drawn on the basis of the topographic maps in the scale of 1:50 000, were used in this study (Table 1). In terms of the photogrammetric material, the aerial images taken in 2005 and 2010 and processed into orthophotos were used (Table 1).

The basic tool used to analyse the changes in the lake surface area and to prepare the cartographic

Table 1. List of cartographic and photogrammetric sources used in the study

\begin{tabular}{|c|c|c|c|}
\hline \multicolumn{2}{|c|}{ Source } & \multirow{2}{*}{ Scale } & \multirow{2}{*}{ Published } \\
\hline Map & Sheet & & \\
\hline $\begin{array}{l}\text { German } \\
\text { topographic map } \\
\text { (Meßtischblatt) }\end{array}$ & $\begin{array}{l}2377 \text { (985) } \\
\text { Rinkowen }\end{array}$ & $1: 25000$ & 1910 \\
\hline $\begin{array}{l}\text { German } \\
\text { topographic map } \\
\text { (Meßtischblatt) }\end{array}$ & $\begin{array}{l}2377 \text { (985) } \\
\text { Rinkowen }\end{array}$ & $1: 25000$ & 1938 \\
\hline Topographic map & 335.3 Nowe & $1: 50000$ & 1969 \\
\hline Topographic map & 335.32 Czerwińsk & $1: 25000$ & 1973 \\
\hline Topographic map & 335.34 Nowe & $1: 25000$ & 1973 \\
\hline Topographic map & 335.323 Rynkówka & $1: 10000$ & 1991 \\
\hline Topographic map & 335.341 Mątasek & $1: 10000$ & 1991 \\
\hline $\begin{array}{l}\text { Orthophotomap } \\
\text { (black and white) }\end{array}$ & $\begin{array}{l}\text { N-34-74-C-c-3-2 } \\
\text { N-34-74-C-c-3-4 } \\
\text { N-34-74-C-c-4-1 } \\
\text { N-34-74-C-c-4-3 } \\
\text { N-34-86-A-a-1-2 } \\
\text { N-34-86-A-a-1-3 } \\
\text { N-34-86-A-a-1-4 } \\
\text { N-34-86-A-a-2-1 } \\
\text { N-34-86-A-a-3-1 } \\
\text { N-34-86-A-a-3-2 }\end{array}$ & $1: 5000$ & 2005 \\
\hline $\begin{array}{l}\text { Hydrographic } \\
\text { map }\end{array}$ & N-34-74-C Skórcz & $1: 50000$ & 2006 \\
\hline $\begin{array}{l}\text { Hydrographic } \\
\text { map }\end{array}$ & N-34-86-A Nowe & $1: 50000$ & 2008 \\
\hline & $\begin{array}{l}\text { N-34-74-C-C-3-2 } \\
\text { N-34-74-C-C-3-4 } \\
\text { N-34-74-C-C-4-1 } \\
\text { N-34-74-C-C-4-3 }\end{array}$ & & \\
\hline $\begin{array}{l}\text { Orthophotomap } \\
\text { (RBG) }\end{array}$ & $\begin{array}{l}\text { N-34-86-A-a-1-2 } \\
\text { N-34-86-A-a-1-3 } \\
\text { N-34-86-A-a-1-4 } \\
\text { N-34-86-A-a-2-1 } \\
\text { N-34-86-A-a-3-1 } \\
\text { N-34-86-A-a-3-2 }\end{array}$ & $1: 5000$ & 2010 \\
\hline
\end{tabular}


visualisation of the transformation taking place was the ArcGIS application ver. 9.3. At the beginning, all the cartographic and remote sensing materials were transformed into the National Geodetic Coordinate System (Państwowy Układ Wspótrzędnych Geodezyjnych PUWG) 1992. Subsequently, the vectorisation of lakeshores of the discussed lakes was carried out, followed by the calculation of the surface areas of the obtained polygons.

The oldest data on the surface areas of the lakes obtained from the Topografische Karte was compared, in chronological order, with the current data obtained from the topographic maps and the orthophotos. In the case of Lake Udzierz, the morphometric data included in the bathymetric plan drawn up by the Inland Fisheries Institute in Olsztyn (Instytut Rybactwa Sródlądowego IRS) were taken into consideration (IRS 1964). In addition, the hydrography of both lakes contained in the 2006 hydrographic map in the scale of 1:50 000 was verified.
The use of cartographic materials in different scales and of varying degrees of detail of cartographic content constituted a certain limitation to the accuracy of the assessment of the temporal changes in the morphometry of the examined lakes. For this reason, the analysis of the morphometric changes is limited to a single parameter, i.e. the water surface area, which is the least "sensitive" parameter to the influences of the map scale (unlike, for example, the lakeshore length) (Håkanson 1981).

\section{Study area}

Lakes Udzierz $\left(53^{\circ} 39.8^{\prime} \mathrm{N}, 18^{\circ} 33.3^{\prime} \mathrm{E}\right)$ and Mątasek $\left(53^{\circ} 39.1^{\prime} \mathrm{N}, 18^{\circ} 32.3^{\prime} \mathrm{E}\right)$ are located in the ethno-cultural region of Kociewie, part of the physico-geographical mesoregion of the Tuchola Forest (Kondracki 2004). In terms of the hydrographic classification of Poland, both lakes are located in the headwaters of the catchment of the River Mątawa, which is a left tributary of the River Vistula (Fig. 1).
Fig. 1. Location of Lakes Udzierz and Mątasek

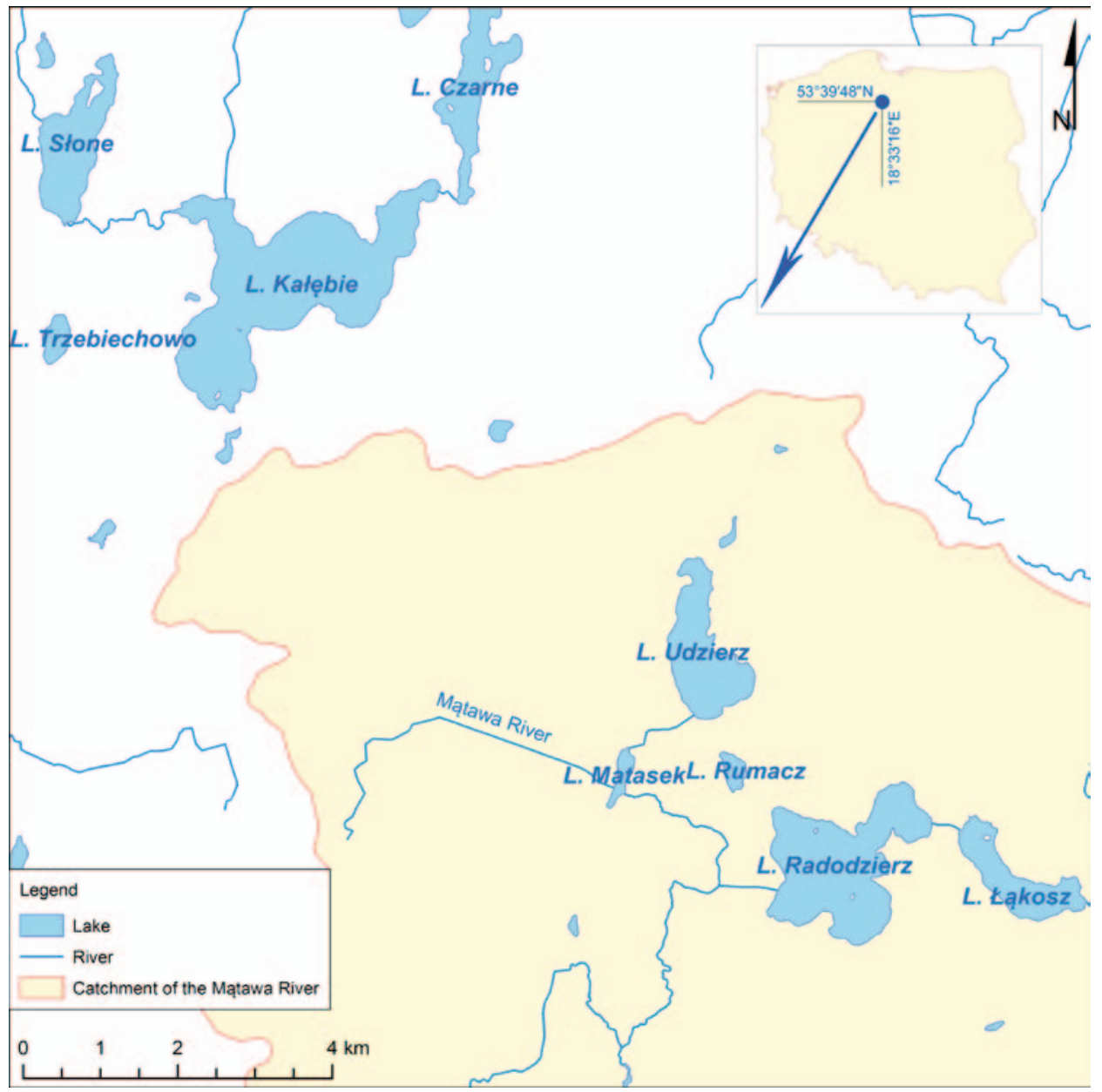


The lakes fill up natural kettle holes which developed on the outwash plain of the Pomeranian Phase of the Weichselian Glaciation, which is presently covered with pine forest. The dominant forms of land use in the immediate vicinity of the water bodies, however, are grasslands (meadows and pastures) and peat bogs. The area is drained and cut by drainage canals, the total length of which in the 1-km buffer zone from the lakeshores is $34.5 \mathrm{~km}$ in the case of Lake Udzierz and 14.5 $\mathrm{km}$ in the case of Lake Matasek. The lakes are shallow with a maximum depth of $2.1 \mathrm{~m}$ (Lake Udzierz).

Since 2000 Lake Udzierz has been a nature reserve created to protect the diversity of avifauna. The reserve encompasses Lake Udzierz with the surrounding rushes, bogs and meadows.

\section{Lake area changes}

In the century of 1910-2010 the water surface area of Lake Udzierz decreased by over 53\% (Table 2).

The largest water surface area of Lake Udzierz was recorded in 1910 and amounted to 148.9 ha. Its shoreline remained relatively unchanged until the end of the 1930s. In addition to the main basin the lake had two bays located in its northern part (Fig. 2). By 1969 the bays had disappeared completely, resulting in a decrease in the size of the lake by more than 20 ha. In the topographic maps from the years 1969, 1973 and 1991 the course of the lakeshore is similar. During this period, the water surface area decreased slightly (by $4.82 \mathrm{ha}$ ) and in 1991 reached 121.4 ha (Table 2).

The greatest rate of the reduction in the water surface area of Lake Udzierz was registered after 1991. In just 14 years, i.e. by 2005, its water surface area had decreased by more than 50 ha and by 2010 by a fur- ther 1.4 ha (Fig. 2). At that time, the lake's surface area had decreased by nearly $43 \%$, and the northern part of the lake totally disappeared. The lake was then divided into two basins: the main one in the south and a smaller one in the north. In 2005 the water surface area of the main water body was 68.3 ha, while that of the northern one was just 2.71 ha. In 2010 these values were 64.6 ha and 5 ha, respectively. Such drastic changes in the lake morphometry, however, were not recorded by the current hydrographic map of 2006, where the lake has the area 1.15 ha larger than in the topographic map of 1991.

Lake Mątasek, located a short distance from Lake Udzierz, also underwent significant morphometric transformation. Over the last century, the water surface area of this lake fell by as much as $98 \%$, from 29.5 ha in 1910 to only 0.64 ha in 2010 (Table 3). Originally, it had an elongated lake basin. Currently, the lake has an oval outline of the shoreline, so characteristic of most kettle holes (Fig. 3).

The largest changes in the morphometry of Lake Mątasek, as in the case of Lake Udzierz, were recorded after World War II (Table 3). Over 31 years (1938-1969) it decreased by approximately 19 ha, which accounted for nearly $64 \%$ of its original water surface area (Table 3 ). The southern part of the lake disappeared, and in the central part of the former basin a bay developed (Fig. 3). A further reduction in the lake surface area was recorded in the period between 1991 and 2010. By 2005, the reservoir was reduced by approximately 9 ha, and by 2010 by a further 2 ha. The hydrographic map of 2008 does not show such drastic changes in the water surface area of the lake; it is smaller by approximately 6.13 ha if compared with the topographic map of 1991 (Table 3).

Table 2. Water surface area changes of Lake Udzierz in the years 1910-2010

\begin{tabular}{|c|c|c|c|c|c|}
\hline \multirow{2}{*}{ Data source } & \multirow{2}{*}{ Scale } & \multirow{2}{*}{ Published } & \multirow{2}{*}{$\begin{array}{c}\text { Water surface area } \\
\text { [ha] }\end{array}$} & \multicolumn{2}{|c|}{ Change in the water surface area } \\
\hline & & & & [ha] & {$[\%]$} \\
\hline Topographische Karte & $1: 25000$ & 1910 & 148.87 & 0.00 & 0.00 \\
\hline Topographische Karte & $1: 25000$ & 1938 & 148.87 & 0.00 & 0.00 \\
\hline Bathymetric plan by the IRS & - & 1964 & 132.70 & -16.17 & 10.9 \\
\hline Topographic map & $1: 50000$ & 1969 & 128.11 & -20.76 & 13.9 \\
\hline Topographic map & $1: 25000$ & 1973 & 126.23 & -22.64 & 15.2 \\
\hline Topographic map & $1: 10000$ & 1991 & 121.41 & -27.46 & 18.5 \\
\hline Orthophoto & $1: 5000$ & 2005 & 71.00 & -77.87 & 52.3 \\
\hline Hydrographic map & $1: 50000$ & 2006 & 122.56 & -26.31 & 17.7 \\
\hline Orthophotomap & $1: 5000$ & 2010 & 69.60 & -79.27 & 53.3 \\
\hline
\end{tabular}




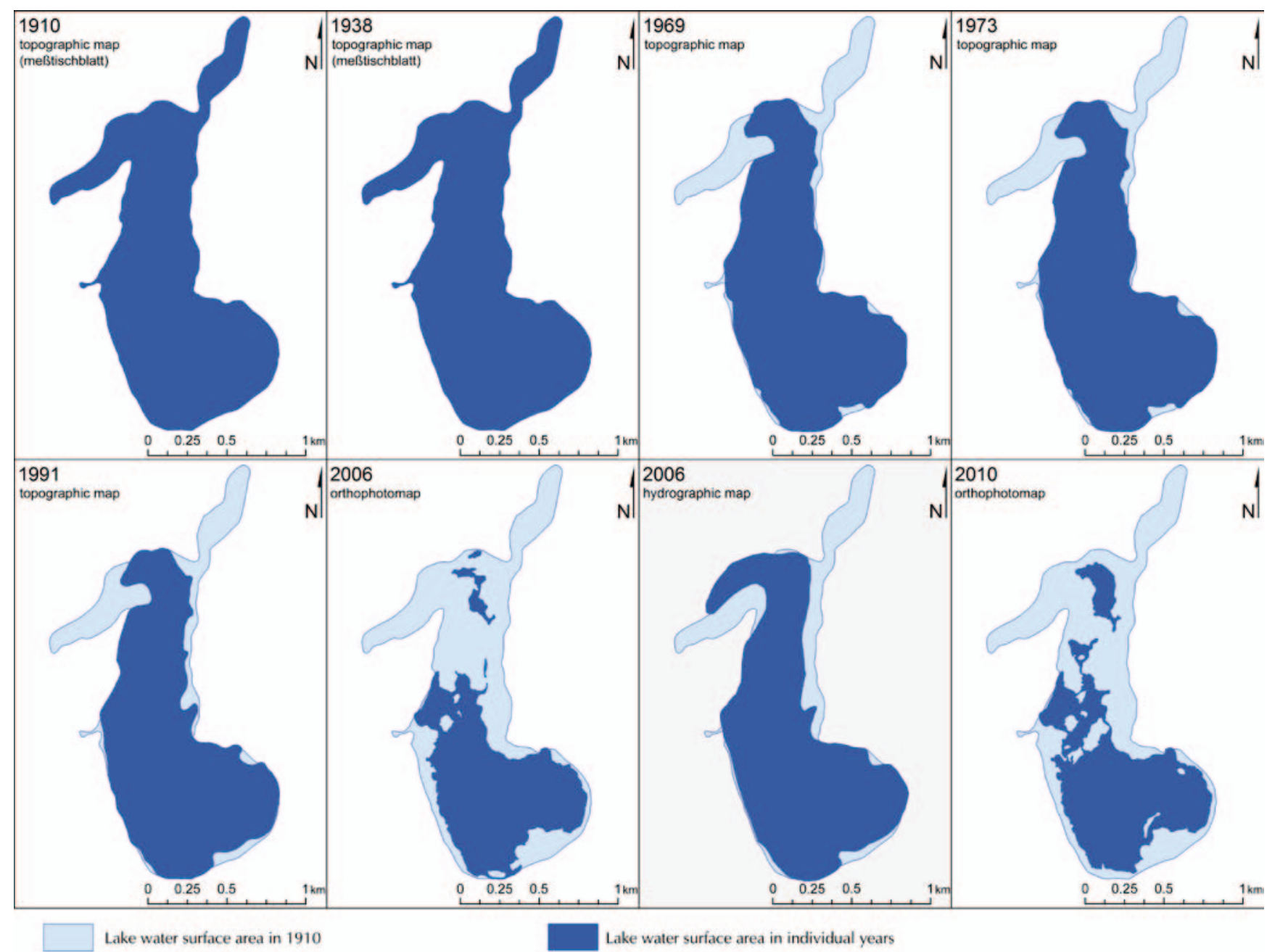

Fig. 2. Water surface area of Lake Udzierz according to different cartographic sources from the years 1910-2010

Table 3. Water surface area changes of Lake Mątasek in the years 1910-2010

\begin{tabular}{|c|c|c|c|c|c|}
\hline \multirow{2}{*}{ Data source } & \multirow{2}{*}{ Scale } & \multirow{2}{*}{ Published } & \multirow{2}{*}{$\begin{array}{c}\text { Water surface area } \\
{[\mathrm{ha}]}\end{array}$} & \multicolumn{2}{|c|}{ Change in the water surface area } \\
\hline & & & & [ha] & {$[\%]$} \\
\hline Topographische Karte & $1: 25000$ & 1910 & 29.55 & 0.00 & 0.00 \\
\hline Topographische Karte & $1: 25000$ & 1938 & 29.55 & 0.00 & 0.00 \\
\hline Topographic map & $1: 50000$ & 1969 & 10.72 & -18.83 & 63.7 \\
\hline Topographic map & $1: 25000$ & 1973 & 10.72 & -18.83 & 63.7 \\
\hline Topographic map & $1: 10000$ & 1991 & 11.68 & -17.88 & 60.5 \\
\hline Orthophoto & $1: 5000$ & 2005 & 2.71 & -26.84 & 90.8 \\
\hline Hydrographic map & $1: 50000$ & 2008 & 4.55 & -25.01 & 84.6 \\
\hline Orthophotomap & $1: 5000$ & 2010 & 0.64 & -28.92 & 97.8 \\
\hline
\end{tabular}




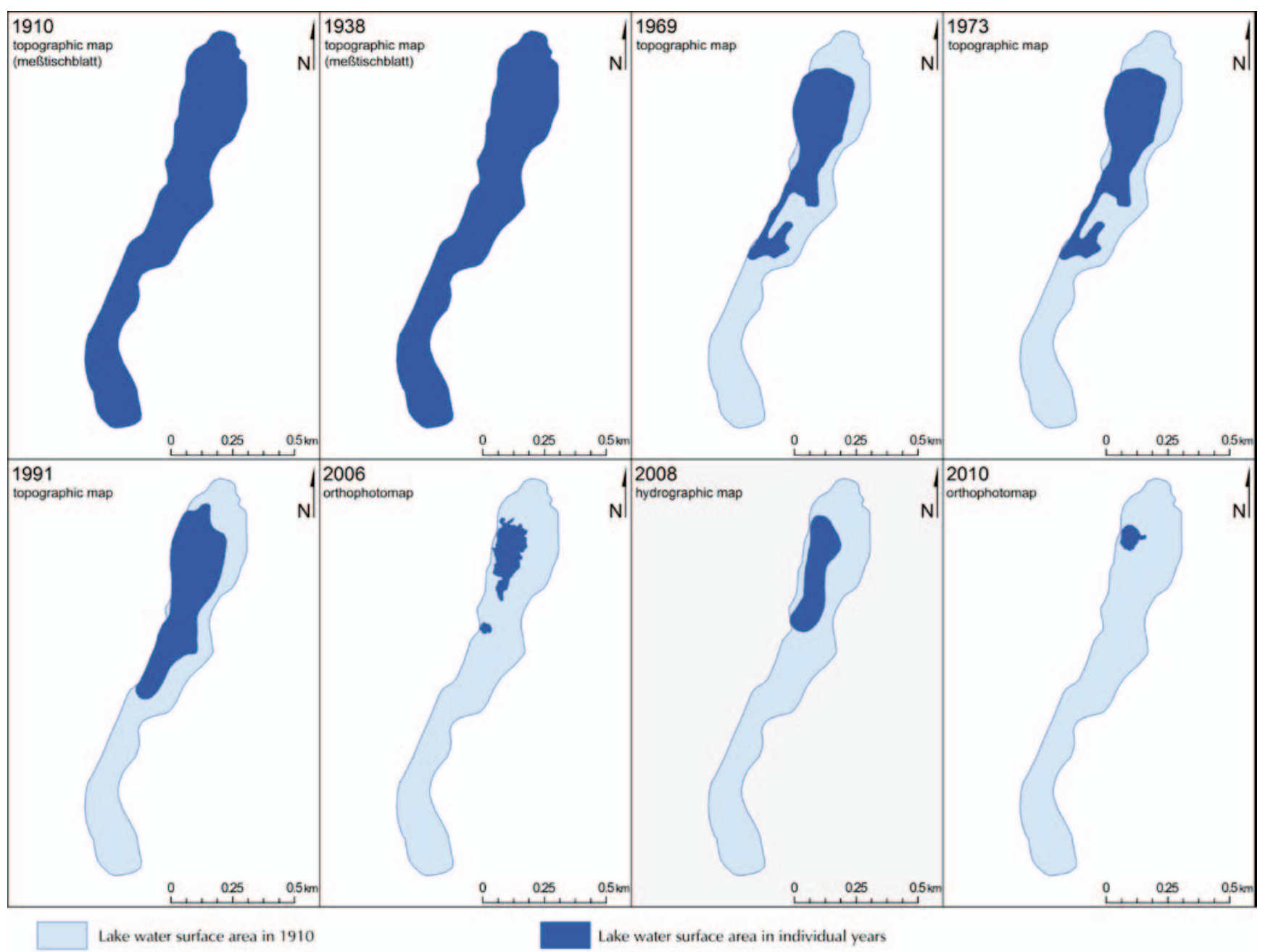

Fig. 3. Water surface area of Lake Mątasek according to different cartographic sources from the years 1910-2010

\section{Discussion}

The age of the glacial lakes in northern Poland is determined to be approximately 10-12,000 years. Until the first extensive drainage work, aiming to intensify the agricultural production and the economic exploitation of the region, the disappearance of the lakes was determined primarily by natural factors. The average annual rate of the decrease in the water surface area of water bodies in northern Poland during their natural functioning was $\sim 0.007 \%$, with the locally maximum values of less than $0.01 \%$ per annum (Galon 1954; Kalinowska 1961). In the conditions of the growing anthropopressure, the disappearance rate has increased by one or two orders of magnitude, and in the last century in many lake district areas it amounted to $0.20-0.25 \%$ per annum (Marszelewski and Podgórski 2004; Nowacka and Ptak, 2007). Even in the areas with large and deep ribbon lakes the disappearance rate is 4-5 times faster today than in the undisturbed conditions (Marszelewski and Adamczyk 2004; Czaja and Jańczak 2010).

In the case of the studied lakes, in the years 1910-2010 their water surface area was reduced by 53.3\% (Lake Udzierz) and 97.8\% (Lake Mąasek) (Tables 2-3), and the average disappearance rate during this period was, respectively, 0.53 and $0.98 \%$ per annum. This means they are now two of the fastest disappearing Polish lakes.

The disappearance process of the two lakes shows clear stages associated with the ongoing drainage. Such activities were undertaken in the valley of the River Mątawa several times. The triggered hydrological changes in the lakes' surroundings were accompa- 


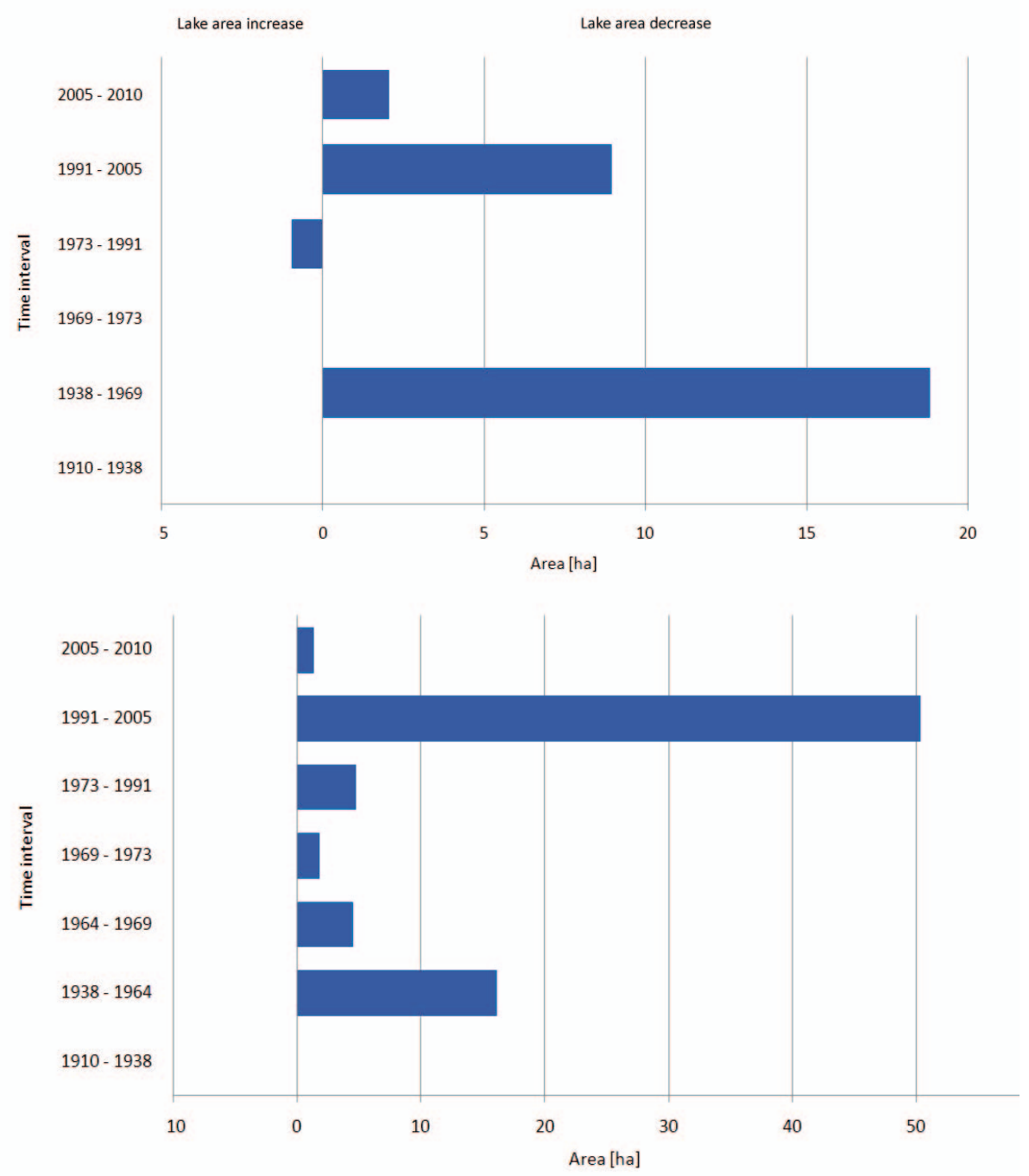

Fig. 4. Changes in the water surface area of Lake Udzierz (upper) and Lake Mątasek (lower) in selected periods of time within the century of 1910-2010

nied by a clearly visible change in the range of their water surface area. The stable shape of the surface of the lakes, which continued until the end of the 1930s, resulted from the $19^{\text {th }} \mathrm{c}$. drainage works. At the same time, obligatory water management in the valley of the River Mątawa was implemented within the framework of the Embankment Association of the Mątawa Valley (Związek Wałowy Doliny Mątawy), whose task was to carry out works including drainage and maintenance of the existing network of canals and drainage facilities.

The drainage work conducted once again at the end of the 1950s resulted in a further reduction in the groundwater levels and, consequently, a decrease in the water surface area of the lakes (Fig. 4). The new state of relative equilibrium was reached by the lakes only at the turn of the 1960s and 1970s. At that time the average annual rate of the disappearance of the lakes was $0.43 \%$ in the case of Lake Udzierz, and as much as $1.82 \%$, in the case of Lake Martasek. With regard to the latter, the lake surface area decreased by 18.8 ha, i.e. nearly $64 \%$, in just three decades (Table 3 ).

The next phase of very rapid loss of the water surface area of the lakes was recorded in the years 1991-2005. It was a consequence of the accelerated eutrophication and overgrowth of both water bodies. The natural processes of autogenous accumulation of organic matter were intensified due to excessive inflow of nutrients from the nearby farmland (Przewoźniak 
1991). In the case of Lake Udzierz the acceleration of the eutrophication process was also significantly influenced by the earlier drainage works. Lowering of the groundwater levels and, consequently, a decrease in the hydrological yield of the rivers feeding the lake, and, above all, redirecting the River Mątawa directly into Lake Mątasek (omitting Lake Udzierz), detrimental to the ecosystem of the lake, reduced the water inflow to the lake by about 20-25\% (Lange 1991). Thus, the rate of irrigation of the lake significantly decreased and the nutrient cycle slowed down. In the case of Lake Mątasek, however, the key factor was the intensification of the water outflow from the lake and the reduction of the local erosion base, which brought the lake to an almost complete disappearance.

The fifteen years covering the years 1991-2005 proved to be the period of the fastest decline in the water surface area of the studied lakes (Fig. 4). During this time, the surface area of the lakes decreased by as much as several percent per annum. This process was the most extensive in Lake Mątasek, whose surface area decreased at an average rate of $5.12 \%$ per annum. At this time the average annual rate of the disappearance of Lake Udzierz was slower by half and was $2.77 \%$.

\section{References}

Bai J., Chen X., Li J., Yang L., Fang H., 2011, Changes in the area of inland lakes in arid regions of central Asia during the past 30 years, Environ. Monit. Assess. 178(1-4): 247-256.

Belyaev A.V., 1995, Water balance and water resources of the Aral Sea basin and its men-induced changes, GeoJournal 35(1): 17-21.

Babiński Z., 1988, Wpływ melioracji na zmiany zwierciadła i powierzchni wody jeziora Pniewite (Influence of land reclamation on changes in water level and water area of Lake Pniewite), [in:] Churski Z. (ed.), Naturalne i antropogeniczne przemiany jezior i mokradeł w Polsce (Natural and anthropogenic transformations of lakes and wetlands in Poland), Wyd. UMK, Toruń: 101-104 (in Polish).

Choiński A., Ławniczak A., Ptak M., Sobkowiak L., 2011, Causes of Lake Area Changes in Poland, J. Resour. Ecol. 2(2): 175-180.

Churski Z., 1983, Eutrophication and the disappearance of lakes in the Brodnica Lake District, Northern Poland as a result of human interference, Hydrobiologia 103: 165-168.

Czaja K., Jańczak J., 2010, Zanikanie jezior w dorzeczu Raduni w ostatnim stuleciu (Lakes disappearance in Radunia River basin over the last century), [in:] Choiński A. (ed.), Przemiany jezior i zbiorników wodnych (Transformations of lakes and reservoirs), Bogucki Wyd. Nauk., Poznań: 55-67 (in Polish, English summary).
Dudgeoni D., Arthington A.H., Gessner M.O., Kawabata Z.I., Knowler D.J., Lévêque C., Naiman R.J., Prieur-Richard A.H., Soto D., Stiassny M.L.J., Caroline A. Sullivan C.A., 2006, Freshwater biodiversity: importance, threats, status and conservation challenges, Biol. Rev. 81: 163-182.

Du Y., Xue H.P., Wu S.J., Ling F., Xiao F., Wei X.H., 2011, Lake area changes in the middle Yangtze region of China over 20th century, J. Environ. Manage. 92(4): 1248-1255.

Galon R., 1954, Wstępna wiadomość o opracowaniu dotyczącym zanikania jezior w Polsce (Preliminary communication on a paper concerning the disappearance of lakes in Poland), Prz. Geogr. 26(2): 81-91 (in Polish, English summary).

Gao H., Bohn T.J., Podest E., McDonald K.C., Lettenmaier D.P., 2011, On the causes of the shrinking of Lake Chad, Environ. Sci. Lett. 6(3): 034021 (7pp): doi:10.1088/17489326/6/3/034021

Håkanson L., 1981, Lake Morphometry, Springer, BerlinHeidelberg-New York, p. 78.

Hillbricht-Ilkowska A., 2005, Ochrona jezior i krajobrazu pojeziernego - Problemy, procesy, perspektywy (Protection of lakes and lakelands: Problems, processes, perspectives), Kosmos 54(2/3): 285-302 (in Polish, English summary).

Huang L., Liu J., Shao Q., Liu R., 2011, Changing inland lakes responding to climate warming in Northeastern Tibetan Plateau, Climatic Change 109(3-4): 479-502.

Jureko L., 1969, Przyczyny zanikania Jeziora Chełmżyńskiego w świetle bilansu jego zlewni (Causes of the Chełmżyńskie Lake decline considering its basin budget), Pr. PIHM 96: 93-106 (in Polish, English summary).

Kawanabe H., Nishino M., Maehata M. (eds), 2012, Lake Biwa: Interactions between Nature and People, Springer, Dordrecht, p. 744.

Kalinowska K., 1961, Zanikanie jezior polodowcowych w Polsce (Disappearance of the post-glacial lakes on the territory of Poland), Prz. Geogr. 33(3): 511-518 (in Polish, English summary).

Kondracki J., 2004, Geografia regionalna Polski (Regional geography of Poland), PWN, Warszawa, p. 468 (in Polish).

Kopytowski C., 1931, Jeziorka efemeryczne na obszarze wydmowym Warciańsko-Noteckim (Ephemeral lakelets on the Warta-Noteć dune area), Bad. Geogr. 6/7: 125-135 (in Polish, French summary).

Kostrzewski A. (ed.), 1993, Geoekosystem obszarów nizinnych (Geoecosystem of lowland areas), Zesz. Nauk. Kom. Nauk “Człowiek i Środowisko" PAN 6: 1-180 (in Polish, English summary).

Kunz M., Skowron R., Skowroński S., 2010, Morphometry changes of Lake Ostrowskie (the Gniezno lakeland) on the basis of cartographic, remote sensing and geodetic surveying, Limnol. Rev. 10(2): 77-85.

Lange W., 1986, Fizyczno-limnologiczne uwarunkowania tolerancji systemów jeziornych Pomorza (Physico-limnologic conditioning of the Pomeranian lake systems' tolerance), Zesz. Nauk. UG, Rozpr. Monogr. 79: 1-177 (in Polish, English summary). 
Lange W., 1991, Hydrologiczne uwarunkowania eutrofizacji jeziora Udzierz (Hydrological conditioning of the eutrophication of Lake Udzierz), [in:] Przewoźniak M. (ed.), Dokumentacja przyrodnicza projektowanego rezerwatu przyrody "Jezioro Udzierz" (Natural documentation of the designed nature reserve „Lake Udzierz”) [Manuscript], BPiWP “PROEKO”, Gdańsk: 55-65 (in Polish).

Marszelewski W., Podgórski Z., 2004, Zmiany ilościowe oczek i jezior na Pojezierzu Chełmińskim w świetle materiałów kartograficznych z XIX i XX wieku (Quantitative changes of the kettle lakes and other lakes located in the Chełmińskie Lakeland in the light of cartographic materials from the 19th and 20th centuries), Prz. Geogr. 76(1): 33-50 (in Polish, English summary).

Marszelewski W., 2005, Zmiany warunków abiotycznych w jeziorach Polski Północno-Wschodniej (Changes in the abiotic conditions in the lakes of North-East Poland), Wyd. Nauk. UMK, Toruniu, p. 288 (in Polish, English summary).

Marszelewski W., Adamczyk A., 2004, Changes in the area of the Mazurian Lakes in the light of the cartographic materials at the scale 1:25 000, Limnol. Rev. 4: 167-176.

Nowacka A., Ptak M., 2007, Zmiany powierzchni jezior na Pojezierzu Kujawsko-Wielkopolskim w XX w (The change in the surface area of lakes in the Wielkopolsko-Kujawskie Lake District in the 20th century), Bad. Fizjogr. Pol. Zach. A 58: 149-157 (in Polish, English summary).

Przewoźniak M., 1991, Charakterystyka fizycznogeograficzna rezerwatu i jego otoczenia (Physical-geographical characteristics of the reserve and its surrounding), [in:] Przewoźniak M. (ed.), Dokumentacja przyrodnicza projektowanego rezerwatu przyrody "Jezioro Udzierz" (Natural documentation of the designed nature reserve „Lake Udzierz”) [Manuscript], BPiWP “PROEKO”, Gdańsk: 7-11 (in Polish).
Rossolimo L.L., 1964, Osnovy tipizatsii ozer i limnologicheskogo raionirovania (Principles of lake typification and limnological division into districts), [in:] Rossolimo L.L. (ed.), Nakoplenie veshchestva v ozerakh (Substance accumulation in lakes), Izd. Nauka, Moskva: 5-46 (in Russian).

Sarch M.T., 2001, Fishing and farming at Lake Chad: institutions for access to natural resources, J. Environ. Manage. 62(2): 185-199.

Sidle R.C., Ziegler A.D., Vogler J.B., 2007, Contemporary changes in open water surface area of Lake Inle, Myanmar, Sustain. Sci. 2: 55-65.

Stangenberg M., 1936, Szkic limnologiczny na tle stosunków hydrochemicznych Pojezierza Suwalskiego. "Suchar" i "Jeziorko" jako stadjum przejściowe zanikania jezior (Limnological sketch relating to hydrochemical relationships in the Suwałki Lakeland. "Suchar"- and "Jeziorko"- lakes as the transitional stage of lakes disappearing), Pr. Inst. Bad. Lasów Państw. A 19: 1- 85 (in Polish, German summary).

Starkel L., 1977, Paleogeografia holocenu (Paleogeography of the Holocene), PWN, Warszawa, p. 366 (in Polish).

Tranvik L.J., Downing J.A., Cotner J.B., Loiselle S.A., Striegl R.G., Ballatore T.J., Dillon P., Finlay K., Fortino K., Knoll L.B., Kortelainen P.L., Kutser T., Larsen S., Laurion I., Leech D.M., McCallister S.L., McKnight D.M., Melack J.M., Overholt E., Porter J.A., Prairie Y., Renwick W.H., Roland F., Sherman B.S., Schindler D.W., Sobek S., Tremblay A., Vanni M.J., Verschoor A.M., von Wachenfeldt E., Weyhenmeyera G.A., 2009, Lakes and reservoirs as regulators of carbon cycling and climate, Limnol. Oceanogr. 54(6, part 2): 2298-2314.

Vollenweider R.A., 1970, Scientific fundamentals of the eutrophication of lakes and flowing waters, with particular reference to nitrogen and phosphorus as factors in eutrophication, OECD, Paris, p. 159. 